\title{
Comparison between Otoliths and Length Based Ageing and Growth of African Armoured Searobin (Peristedion cataphractum L. 1758; Teleostei, Peristediidae) off the Southern Coasts of Sicily (Mediterranean Sea)
}

\author{
Teresa Bottari, ${ }^{1}$ Salvatore Gancitano, ${ }^{2}$ Paola Rinelli, ${ }^{1}$ and Sergio Ragonese ${ }^{2}$ \\ ${ }^{1}$ Institute for Coastal Marine Environment (IAMC), National Research Council (CNR), Spianata S. Raineri 86, 98122 Messina, Italy \\ ${ }^{2}$ Institute for Coastal Marine Environment (IAMC), National Research Council (CNR), Via L. Vaccara 61, \\ 91026 Mazara del Vallo, Italy \\ Correspondence should be addressed to Teresa Bottari; teresa.bottari@iamc.cnr.it
}

Received 8 July 2015; Accepted 15 September 2015

Academic Editor: Jakov Dulčić

Copyright (C) 2015 Teresa Bottari et al. This is an open access article distributed under the Creative Commons Attribution License, which permits unrestricted use, distribution, and reproduction in any medium, provided the original work is properly cited.

\begin{abstract}
The recovering of Peristedion cataphractum otoliths collected between 1991 and 1992 from specimens sampled off the southern coasts of Sicily has allowed a direct ageing and growth estimation to be compared with the length based method estimates produced in successive years. Overall, 855 left otoliths (sagittae) were recovered, measured, and read as a whole surface. The core and rings distances were also measured to perform back-calculation. The otolith length-body length relationships were allometric. Back-calculated lengths at age were in agreement with the lengths estimated with otolith readings. Present results showed a good congruency between otoliths and length based method.
\end{abstract}

\section{Introduction}

Peristedion cataphractum (L. 1758) is a demersal species distributed in the Eastern Atlantic and Mediterranean Sea [1]. It occurs on muddy bottoms, between 50 and $848 \mathrm{~m}$ ( $\max$ depth reported), showing a preference for the upper slope (201-500 m) [1-4].

The available information on the life history of $P$. cataphractum has been recently reviewed $[4,5]$. The eggs are spawned from May to October; recruits occur continuously from September to March, but the recruitment peak is from late December through March. The size at onset of sexual maturity $\left(L_{m}\right.$ at $\left.50 \%\right)$ is achieved at 191 and $212 \mathrm{~mm}$ for females and males, respectively. The growth of $P$. cataphractum has been examined along the southern coasts of Sicily (Mediterranean Sea) by applying length based methods (LBMs). Up to five significant modal components were evidenced, with the first 2-3 being well distinguished. Two sets of the special von Bertalanffy function were derived reflecting juveniles/adult $\left(L_{\infty}=380 \mathrm{~mm}, K y^{-1}=0.34\right.$, and $\left.t_{0} y=-0.76\right)$ and adults $\left(L_{\infty}=313 \mathrm{~mm}, K y^{-1}=0.28\right.$, and $\left.t_{0} y=-0.99\right)$ growth trajectories [4].

The suitability of the LBM, even in stock showing discrete recruitment such as $P$. cataphractum, has been criticized by many authors, and comparison with direct ageing method was strongly suggested [6-9]. The main drawbacks of LBM (especially in long living species) consist in the difficulty to distinguish the oldest cohorts (year classes) given the "pile up" effect due to the growth rate reduction and wide dispersion of lengths at age; that is, medium sized fish might have an age higher than expected; more briefly, LBM methods tend to yield higher $K$ and lower $L_{\infty}$ $[7,8]$.

In the specific case of $P$. cataphractum, the recovering of otoliths sets occasionally collected between 1991 and 1992 off the southern coasts of Sicily has allowed a direct ageing and growth estimation to be compared with the length based growth estimates produced in successive years [4]. 


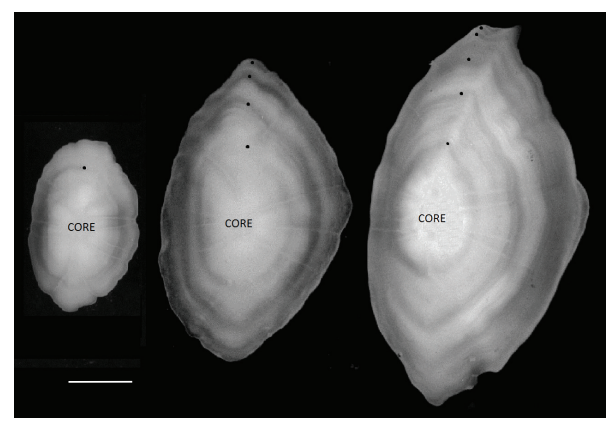

Figure 1: Surface view of the whole otolith (sagitta) of Peristedion cataphractum off the southern coasts of Sicily. From the left to the right: unsexed juvenile ( $\mathrm{TL}=55 \mathrm{~mm}$; age class: 0.5 years), female $(\mathrm{TL}=227 \mathrm{~mm}$; age class: 3.5 years $)$, and male $(\mathrm{TL}=256$; age class: 4.5 years). Scale bar $=1 \mathrm{~mm}$.

\section{Materials and Methods}

The recovered otoliths were found during a check of the material stored in the ex-IRMA collection. In particular, the otoliths resulting were extracted from specimens gathered by trawling the grounds off the southern coasts of Sicily between 1991 and 1992 [10]. The corresponding fish information (sampling date, haul number, total length, and sex) was derived from the enclosed labels. The otoliths (left sagittae) were taken out from the paper envelope, cleaned, and examined with reflected light under a dissecting microscope $(25 \mathrm{x})$ under a dark background, by reading the translucent zones along the rostrum.

A zone or check was considered "true" only when it was clearly distinguishable along the rostrum. "Blind" readings were independently performed twice in successive times. In case of divergence, the same otolith was read again and the two new counts were compared. In case of persistent divergence, the otolith was rejected and only those counts in fully agreement were maintained for the successive analysis. In particular, among the 855 otoliths recovered, 828 (i.e., 96.8\%) resulted readable, analyzed (following [11] for terminology), measured, and used for both direct and back-calculated size at age estimation.

The radius of the $i$ th band $\left(R_{i}\right)$, that is, the distance from the core of the otolith to the outer margin of the translucent ring, and the radius of the otolith at capture $\left(R_{c}\right)$, distance from the core of the otolith to the periphery, were measured (Figure 1). All measurements were always made along the longest axis of the otolith with an image analysis system.

The relationships between the maximum or ultimate otolith radius $(R)$ and total body length (TL, rostrum included) were determined for unsexed juveniles $(\mathrm{J})$, males $(\mathrm{M})$, females $(\mathrm{F})$, and categories combined (All $=\mathrm{F}+\mathrm{M}+$ J; Sexed $=\mathrm{M}+\mathrm{F}$; JM and JF, 50\% randomly split unsexed plus males and plus females, resp.). The relationships were elaborated according to the natural (Naperian) logarithm transformed allometric equation:

$$
\ln Y=a+b * \ln X
$$

where $Y$ and $X$ are the otolith radius and fish total length while $a$ is the intercept and $b$ is the slope (or allometric coefficient); $a$ and $b$ were estimated by ordinary least squares method within the Mystat software [11]; the linear regression assumptions were checked by performing the analysis of residuals. The isometric condition $\left(H_{0}: b=1\right)$ was tested by Student's $t$-test. The differences between sex and sex categories were tested by an analysis of covariance (ANCOVA).

Putative ages were assigned assuming that one opaque and one translucent zone are formed each year [12] as the general case for triglids [13-20] and other deep demersal Mediterranean stocks [21]. The fish length at which different zones were deposited was back-calculated using the following equation [22]:

$$
\mathrm{TL}_{i}=-\left(\frac{a}{b}\right)+\left[\left(\mathrm{TL}_{c}+\frac{a}{b}\right) *\left(\frac{R_{i}}{R_{c}}\right)\right],
$$

where $\mathrm{TL}_{c}$ is the fish length at capture, $\mathrm{TL}_{i}$ is the fish length at time $i, R_{c}$ is the otolith length at the capture, $R_{i}$ is otolith length at time $i, a$ and $b$ are the intercept and the slope of the fish length-otolith radius relationship.

The size at age data was used to estimate, by implementing the Solver routine in Excel, the von Bertalanffy growth function (VBGF) parameters according to the following formula:

$$
L_{t}=L_{\infty}\left[1-\exp -K\left(t-t_{0}\right)\right]
$$

where $L_{t}$ is the length at age $t, L_{\infty}$ is the maximum (asymptotic) length, $K$ is a measure of the growth rate (the rate at which $L_{\infty}$ is approached), and $t_{0}$ is the theoretical age at $L=0$. Goodness of fit was assessed on the base of mean square error (MSE).

An analysis of the residual sum of squares (ARSS) was employed to compare the VBGF parameters between sexes. The $F$-statistic was calculated as in [22]

$$
F=\frac{\left(\mathrm{RSS}_{\mathrm{p}}-\mathrm{RSS}_{\mathrm{s}}\right) /(3 \times(k-1))}{\mathrm{RSS}_{\mathrm{s}} /(N-3 \times k)},
$$

where $\mathrm{RSS}_{\mathrm{p}}$ is the residual sums of square (RSS) of the VBGF fitted by pooled data (samples from both population pooled), $\mathrm{RSS}_{s}$ is the sum of the RSS of each VBGF fitted to each population, $k$ is the number of samples in the comparison, and $N$ is the total sample size. The calculated $F$ value was then compared with the critical $F$, with $3 \times(k-1)$ and $N-$ $3 \times k$, degrees of freedom for the numerator and denominator, respectively.

\section{Results}

The overall sample features (size number, mean, maximum, minimum, and standard deviation values of the fish total length and otolith length for females, males, and unsexed) are presented in Table 1. The relationship between otolith radius $(R)$ and total length (TL) has been calculated on 828 specimens. 27 unsexed juveniles with TL $>139 \mathrm{~mm}$, a length threshold above which the sex is detectable at naked eye, 
TABLE 1: Descriptive statistics of the samples of Peristedion cataphractum used in the present study.

\begin{tabular}{lccccccc}
\hline \multirow{2}{*}{ Sex } & \multirow{2}{*}{$N$} & \multicolumn{3}{c}{ Otolith radius length $(R ; \mathrm{mm})$} & \multicolumn{3}{c}{ Fish total length (TL; mm) } \\
& & Range & Mean & SD & Range & Mean & SD \\
\hline Females & 515 & $1.3-3.77$ & 2.03 & 0.46 & $102-326$ & 185.4 & 48.64 \\
Males & 212 & $1.38-4.27$ & 2.49 & 0.42 & $125-300$ & 232.9 & 37.01 \\
Unsexed & 128 & $0.74-2.43$ & 1.44 & 0.31 & $53-220$ & 116.6 & 36.1 \\
\hline
\end{tabular}

SD denotes the standard deviation.

TABLE 2: Relationships between otolith radius and fish total length.

\begin{tabular}{lcccccccc}
\hline Sex & $N$ & $a$ & SE $(a)$ & $b$ & SE $(b)$ & $R^{2}$ & MSE & Student's $t$-test $p$ \\
\hline F & 514 & -3.347 & 0.08 & 0.777 & 0.015 & 0.831 & 0.007 & $<0.01$ \\
M & 212 & -3.812 & 0.212 & 0.866 & 0.039 & 0.702 & 0.009 & $<0.01$ \\
J & 102 & -2.563 & 0.18 & 0.617 & 0.039 & 0.713 & 0.008 & $<0.01$ \\
JF & 565 & -3.160 & 0.063 & 0.741 & 0.012 & 0.868 & 0.008 & $<0.01$ \\
JM & 263 & -3.228 & 0.084 & 0.759 & 0.016 & 0.897 & 0.009 & $<0.01$ \\
F + M & 726 & -3.480 & 0.068 & 0.803 & 0.013 & 0.841 & 0.008 & $<0.01$ \\
F + M + J & 828 & -3.23 & 0.049 & 0.756 & 0.009 & 0.885 & 0.008 & $<0.01$ \\
\hline
\end{tabular}

$N=$ number of specimens; $\mathrm{F}$ = females; $\mathrm{M}=$ males; $\mathrm{I}=$ unsexed juveniles; $a$ : intercept $b$ : allometry coefficient; $\mathrm{SE}$ : standard error; $R^{2}$ : determination coefficient; MSE: mean square error; probability of Student's $t$-test for differences between allometry coefficient $b$ and "1" (isometric condition).

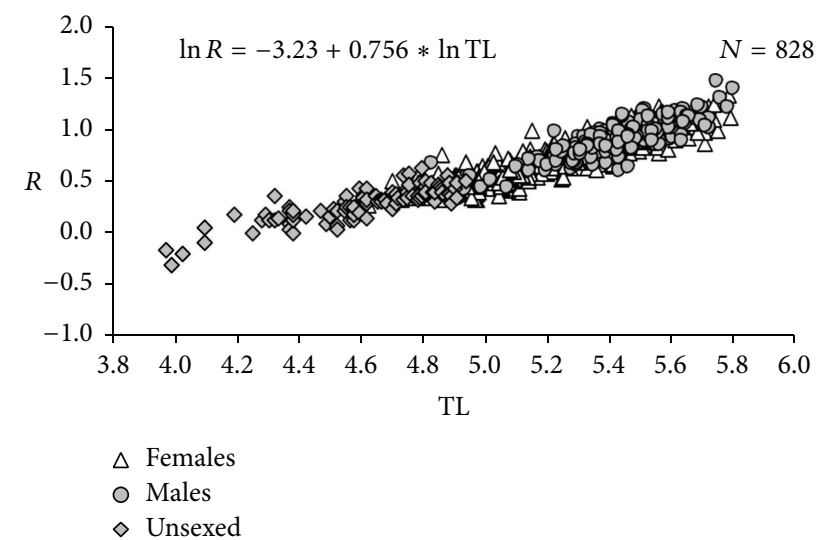

FIGURE 2: Relationship between otolith radius $(R)$ and fish length (TL) and for Peristedion cataphractum off the southern coasts of Sicily. $N$ : number of cases.

and 1 female (outlier) were excluded from analysis (Mystat software). Otolith radius and fish total length were high correlated (Figure 2, Table 2). Otoliths of P. cataphractum exhibited a negative allometry in both sexes (Student's $t$ test, $p<0.01$ ). The relations including juveniles (JF, JM) were stronger (Table 2). The age-length key derived by direct reading of otoliths (Table 3 ) and the plot of mean lengthat-age data of $P$. cataphractum (Figure 3 ) resulted in the identification of up to 11 age classes (the older, however, with very scanty specimens). Age class 1 was the largest with 284 individuals. The first ring represents the settlement (or demersal) ring. The individuals that had only this ring (recruits) formed the 0.5 age class $(50-80 \mathrm{~mm} \mathrm{TL})$. No false ring associable to spawning events was detected. Backcalculated lengths at age were in agreement with the lengths estimated with otolith readings (Figure 3, Table 3).

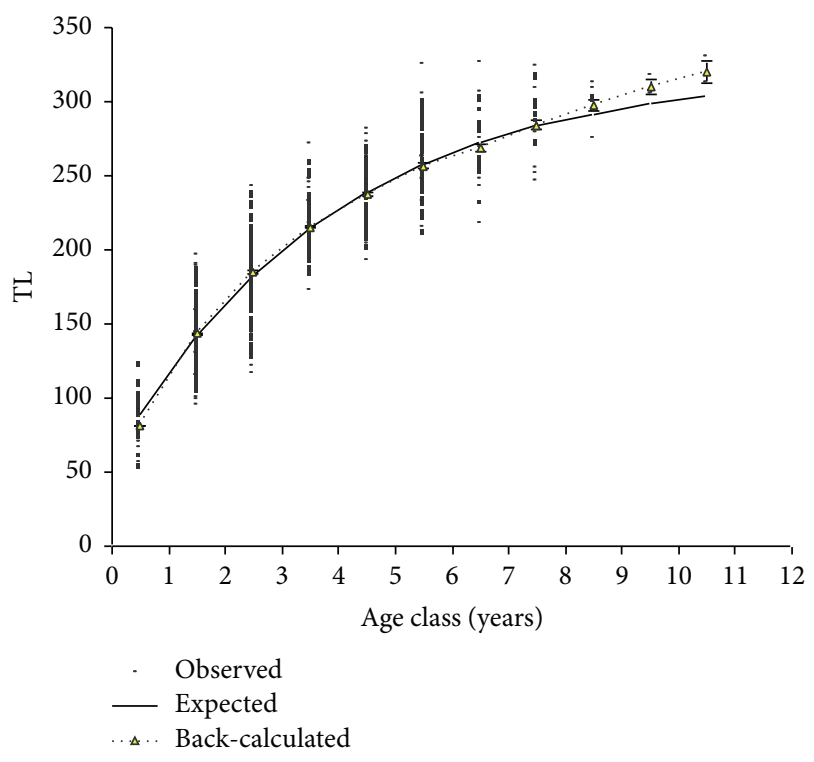

Figure 3: Age-at-total length plot of Peristedion cataphractum (sex combined) off the southern coasts of Sicily with overimposed fitted von Bertalanffy growth function. Solid and dotted lines refer to the curve derived after direct ageing and back calculation, respectively. Bars refer to the standard error; $\mathrm{TL}=$ total length $(\mathrm{mm})$.

The estimated parameters of the VBGF are presented by sex and category in Table 4 . The growth curves generated by VBGF for males and females did not differ between sexes (ARRS F-test $=3.15 ; p=0.065)$.

\section{Discussion}

The otolith morphology was in accordance with the description of [23]; the whole sagitta of P. cataphractum (Figure 1) 
TABLE 3: Age-length key of Peristedion cataphractum estimated after direct ageing and back-calculation.

\begin{tabular}{|c|c|c|c|c|c|c|c|c|c|c|c|c|}
\hline \multirow{2}{*}{ Length class (mm) } & \multicolumn{12}{|c|}{ Age class (years) } \\
\hline & 0.5 & 1.5 & 2.5 & 3.5 & 4.5 & 5.5 & 6.5 & 7.5 & 8.5 & 9.5 & 10.5 & Total \\
\hline 50 & 3 & - & - & - & - & - & - & - & - & - & - & 3 \\
\hline 60 & 3 & - & - & - & - & - & - & - & - & - & - & 3 \\
\hline 70 & 11 & - & - & - & - & - & - & - & - & - & - & 11 \\
\hline 80 & 9 & - & - & - & - & - & - & - & - & - & - & 9 \\
\hline 90 & 17 & 2 & - & - & - & - & - & - & - & - & - & 19 \\
\hline 100 & 9 & 6 & - & - & - & - & - & - & - & - & - & 15 \\
\hline 110 & 2 & 22 & 1 & - & - & - & - & - & - & - & - & 25 \\
\hline 120 & 2 & 38 & 4 & - & - & - & - & - & - & - & - & 44 \\
\hline 130 & - & 57 & 6 & - & - & - & - & - & - & - & - & 63 \\
\hline 140 & - & 64 & 6 & - & - & - & - & - & - & - & - & 70 \\
\hline 150 & - & 35 & 7 & - & - & - & - & - & - & - & - & 42 \\
\hline 160 & - & 34 & 16 & - & - & - & - & - & - & - & - & 50 \\
\hline 170 & - & 19 & 15 & 1 & - & - & - & - & - & - & - & 35 \\
\hline 180 & - & 8 & 31 & 5 & - & - & - & - & - & - & - & 44 \\
\hline 190 & - & 2 & 18 & 20 & 1 & - & - & - & - & - & - & 41 \\
\hline 200 & - & - & 11 & 17 & 5 & - & - & - & - & - & - & 33 \\
\hline 210 & - & - & 11 & 19 & 11 & 3 & 1 & - & - & - & - & 45 \\
\hline 220 & - & - & 9 & 28 & 20 & 3 & - & - & - & - & - & 60 \\
\hline 230 & - & - & 4 & 17 & 13 & 7 & 2 & - & - & - & - & 43 \\
\hline 240 & - & - & 1 & 5 & 19 & 10 & 2 & 1 & - & - & - & 38 \\
\hline 250 & - & - & - & 4 & 12 & 17 & 7 & 2 & - & - & - & 42 \\
\hline 260 & - & - & - & - & 11 & 13 & 2 & - & - & - & - & 26 \\
\hline 270 & - & - & - & 1 & 2 & 5 & 2 & 7 & 1 & - & - & 18 \\
\hline 280 & - & - & - & - & 1 & 9 & 4 & 3 & - & - & - & 17 \\
\hline 290 & - & - & - & - & - & 5 & 2 & 4 & - & - & - & 11 \\
\hline 300 & - & - & - & - & - & 2 & 3 & 2 & 4 & 1 & - & 12 \\
\hline 310 & - & - & - & - & - & - & - & 2 & 1 & 1 & 1 & 5 \\
\hline 320 & - & - & - & - & - & 1 & 1 & 1 & - & - & - & 3 \\
\hline 330 & - & - & - & - & - & - & - & - & - & - & 1 & 1 \\
\hline$d N$ & 56 & 284 & 144 & 117 & 95 & 75 & 26 & 22 & 6 & 2 & 2 & 828 \\
\hline$d_{\text {mean TL }}$ & 87.6 & 142.9 & 181.6 & 217.1 & 237.4 & 259.3 & 268.6 & 284.2 & 299.8 & 311.0 & 321.5 & \\
\hline$d_{\mathrm{SE}}$ & 2.1 & 1.1 & 2.2 & 1.7 & 1.7 & 2.6 & 5.1 & 4.5 & 5.4 & 6.0 & 8.5 & \\
\hline$b_{n}$ & 828 & 772 & 488 & 344 & 227 & 132 & 58 & 32 & 10 & 4 & 2 & \\
\hline$b_{\text {mean TL }}$ & 81.2 & 143.5 & 185.1 & 215.5 & 237.4 & 256.5 & 268.9 & 284.2 & 297.9 & 310.1 & 320.2 & \\
\hline$b_{\mathrm{SE}}$ & 0.5 & 0.7 & 0.9 & 1.0 & 1.3 & 1.9 & 2.9 & 3.1 & 3.5 & 4.5 & 7.2 & \\
\hline
\end{tabular}

$\mathrm{TL}=$ total length; $N$ = number of fish; $d=$ direct; $b$ = back-calculated; $\mathrm{SE}=$ standard error.

TABLE 4: Estimated parameters of the von Bertalanffy growth function (VBGF) for Peristedion cataphractum off the southern coasts of Sicily (central Mediterranean).

\begin{tabular}{|c|c|c|c|c|c|c|c|c|c|}
\hline \multirow{2}{*}{ Sex category } & \multirow{2}{*}{$N$} & \multicolumn{4}{|c|}{ Otolith reading } & \multicolumn{4}{|c|}{ Back-calculation } \\
\hline & & $L_{\infty}$ & $K y^{-1}$ & $-t_{0} y$ & MSE & $L_{\infty}$ & $K y^{-1}$ & $-t_{0} y$ & MSE \\
\hline $\mathrm{F}$ & 514 & 362 & 0.19 & 1.28 & 405.7 & 347 & 0.21 & 0.89 & 477.5 \\
\hline M & 212 & 348 & 0.17 & 2.16 & 392.1 & 339 & 0.19 & 1.66 & 390 \\
\hline JF & 565 & 342 & 0.22 & 0.93 & 434.0 & 315 & 0.29 & 0.41 & 444.6 \\
\hline JM & 263 & 313 & 0.28 & 0.60 & 427.5 & 302 & 0.34 & 0.19 & 401.2 \\
\hline$M+F$ & 726 & 336 & 0.22 & 1.08 & 409.1 & 329 & 0.24 & 0.77 & 435.4 \\
\hline $\mathrm{M}+\mathrm{F}+\mathrm{J}$ & 828 & 321 & 0.26 & 0.76 & 434.2 & 306 & 0.32 & 0.31 & 432.1 \\
\hline
\end{tabular}

$N=$ number; $\mathrm{F}=$ females; $\mathrm{M}=$ males; $\mathrm{JF}=$ unsexed juveniles plus females; JM unsexed juveniles plus males; $L_{\infty}=$ theoretical maximum (asymptotic) total length; $K=$ growth coefficient; $-t_{0}=$ theoretical age at zero length; MSE = mean square error. 
is laterally compressed and left-right symmetrical. The shape is elliptic, with small and round rostrum, and absence of antirostrum. The proximal face shows a homosulcoid, ostial, and median sulcus acusticus. The posterior region is angled.

In our study 11 age groups have been identified. In the eastern Mediterranean Sea [12] up to 7-year-old specimens were found. Females and males seem to have a similar growth rate. The estimated lengths at age were close to those estimated for the eastern Mediterranean Sea [12].

Regarding VBGF estimations, two different growth trajectories by length based method have been reported for P. cataphractum [4]. In particular, the two data sets previously analyzed corresponding to 1994-1998 and 2000-2005 showed differences. In the first period the recruits were well represented in the sample while in the second data set the adult component was prevalent. For this reason two different growth trajectories, that is, juvenile, with higher $L_{\infty}$ and $K$, and the adults with lower $L_{\infty}$ and $K$ were given. The 1994-1998 estimations are more similar to the asymptotic size estimations reported for $P$. cataphractum in the eastern Mediterranean Sea [24] and coherent with the other searobins [13-19]. The lower $L_{\infty}$ and $K$ estimations obtained in the 2000-2005 data sets can be derived from the theoretical approach resumed in [25], which consider the whole growth curve of a given iteroparous and long living stock as the resultant of two growth trajectories, the juvenile (with higher $L_{\infty}$ and $K$ ) and the adults (with lower $L_{\infty}$ and $K$ ), quite overlapping at the transition phase usually coincident with the achievement of sexual maturity.

In this study, the growth curves estimated by combining sexes were more representative and in accordance with adults growth trajectory $\left(L_{\infty}=313 \mathrm{~mm}, K y^{-1}=0.28\right.$, and $t_{0} y=$ $-0.99[4])$.

The results obtained with the back-calculation method were satisfactory as they showed the consistency in the interpretation of the sequence of growth increments.

P. cataphractum represents an appreciable by-catch of shrimp trawl fishery [26] and a significant part in discard of the Mediterranean fisheries. In the context of the "landing obligation" in EU waters, according to which almost all the catch must be landed, this information will help in future ecology based management reforms.

\section{Conflict of Interests}

The authors declare that there is no conflict of interests regarding the publication of this paper.

\section{References}

[1] R. Froese and D. Pauly, "FishBase Editors World Wide Web electronic publication," 2015.

[2] S. Katsanevakis and C. D. Maravelias, "Bathymetric distribution of demersal fish in the Aegean and Ionian Seas based on generalized additive modeling," Fisheries Science, vol. 75, no. 1, pp. 13-23, 2009.

[3] B. Busalacchi, P. Rinelli, F. De Domenico, A. Profeta, F. Perdichizzi, and T. Bottari, "Analysis of demersal fish assemblages off the Southern Tyrrhenian Sea (Central
Mediterranean)," Hydrobiologia, vol. 654, no. 1, pp. 111-124, 2010.

[4] T. Bottari, M. Dimech, G. Nardone, P. Rinelli, and S. Ragonese, "Distribution and biological features of the African armoured searobin, Peristedion cataphractum L. 1758 (Teleostei, Peristediidae) off the southern coasts of Sicily (Mediterranean Sea)," Acta Ichthyologica et Piscatoria, vol. 40, no. 2, pp. 113-127, 2010.

[5] T. Bottari, G. Nardone, P. Rinelli, and S. Ragonese, "Is the African armoured searobin (Peristedion cataphractum, Peristediidae) stock off the south Sicily and North African coasts a "unit stock"?" Cybium, vol. 35, no. 2, pp. 91-98, 2011.

[6] V. J. Isaac, "The accuracy of some length-based methods for fish population studies," Tech. Rep. 27, ICLARM, 1990.

[7] J. A. Gulland and A. A. Rosenberg, "A review of length-based approaches to assessing fish stocks," FAO Fisheries Technical Paper 323, FAO, Rome, Italy, 1992.

[8] G. M. Pilling and A. S. Halls, "Age or length-based methods of growth estimation. What drives the choice?" NAGA, Worldfish Centre Quarterly, vol. 26, no. 2, pp. 4-7, 2003.

[9] A. A. Rosenberg and J. R. Beddington, "Length-based methods of fish stock assessment," in Fish Population Dynamics, J. A. Gulland, Ed., John Wiley \& Sons, Chichester, UK, 2nd edition, 1988.

[10] D. Levi, S. Ragonese, M. G. Andreoli et al., "Sintesi delle ricerche sulle risorse demersali dello Stretto di Sicilia (Mediterraneo centrale) negli anni 1985-1997 svolte nell'ambito della legge 41/82," Biologia Marina Mediterranea, vol. 5, no. 3, pp. 130-139, 1998.

[11] J. Panfili, H. Pontual, H. Troadec, and P. J. Wright, Manual of Fish Sclerochronology, Ifremer-IDR Coedition, Brest, France, 2002.

[12] C. Mytilineou, G. Christidis, A. Terrats, and S. Kavadas, "Preliminary results on the biology of Peristedion cataphractum (L., 1758) in the eastern Ionian Sea," Rapport Commission International Mer Mediterranee, vol. 37, p. 408, 2004.

[13] C. Papaconstantinou, "Age and growth of piper, Trigla lyra, in Saronikos Gulf (Greece)," Cybium, vol. 5, no. 2, pp. 73-87, 1981.

[14] C. Papaconstantinou, "Age and growth of grey gurnard (Eutrigla gurdardus) in the Pagassitikos Gulf (Greece)," Investigacion Pesquera, vol. 46, no. 2, pp. 191-213, 1982.

[15] C. Papaconstantinou, "On the biology of the Lepidotrigla cavillone (family triglidae) of the Greek Seas," Thalassographica, vol. 5, no. 1, pp. 33-59, 1982 (Greek).

[16] C. Papaconstantinou, "Aspects of the biology of Aspitrigla cuculus (L1758) (Pisces: Scorpaeniformes) from the Saranikos Gulf," Thalassographica, vol. 6, pp. 49-75, 1983.

[17] C. Papaconstantinou, "Age and growth of the yellow gurnard (Trigla lucerna L. 1758) from the Thermaikos Gulf (Greece) with some comments on its biology," Fisheries Research, vol. 2, no. 4, pp. 243-255, 1984.

[18] C. Papaconstantinou, "The life history of rock gurnard (Trigloporus lastoviza, Brünn. 1768) in the Saronikos Gulf," Journal of Applied Ichthyology, vol. 2, no. 2, pp. 75-86, 1986.

[19] F. Colloca, M. Cardinale, A. Marcello, and G. D. Ardizzone, "Tracing the life history of red gurnard (Aspitrigla cuculus) using validated otolith annual rings," Journal of Applied Ichthyology, vol. 19, no. 1, pp. 1-9, 2003.

[20] L. Boudaya, L. Neifar, P. Rizzo, C. Badalucco, A. Bouain, and F. Fiorentino, "Growth and reproduction of Chelidonichthys lucerna (Linnaeus) (Pisces: Triglidae) in the Gulf of Gabès, Tunisia," Journal of Applied Ichthyology, vol. 24, no. 5, pp. 581$588,2008$. 
[21] B. Morales-Nin, "Mediterranean deep-water fish age determination and age validation: the state of the art," Fisheries Research, vol. 51, no. 2-3, pp. 377-383, 2001.

[22] R. I. C. C. Francis, "Back-calculation of fish length: a critical review," Journal of Fish Biology, vol. 36, no. 6, pp. 883-902, 1990.

[23] V. M. Tuset, A. Lombarte, and C. A. Assis, "Otolith atlas for the western Mediterranean, north and central eastern Atlantic," Scientia Marina, vol. 72, no. 1, pp. 7-198, 2008.

[24] N. D. Wong, "Mystat: a personal version of Systat," The Yale Journal of Biology and Medicine, vol. 62, no. 2, pp. 237-238, 1989.

[25] J. A. Stamps, M. Mangel, and J. A. Phillips, "A new look at relationships between size at maturity and asymptotic size," American Naturalist, vol. 152, no. 3, pp. 470-479, 1998.

[26] L. Castriota, S. Campagnuolo, and F. Andaloro, "Shrimp trawl fishery by-catch in the straits of Sicily (Central Mediterranean Sea)," Northwest Atlantic Fisheries Organization Serial N4501 NAFO SCR Doc. 01/113, 2001. 

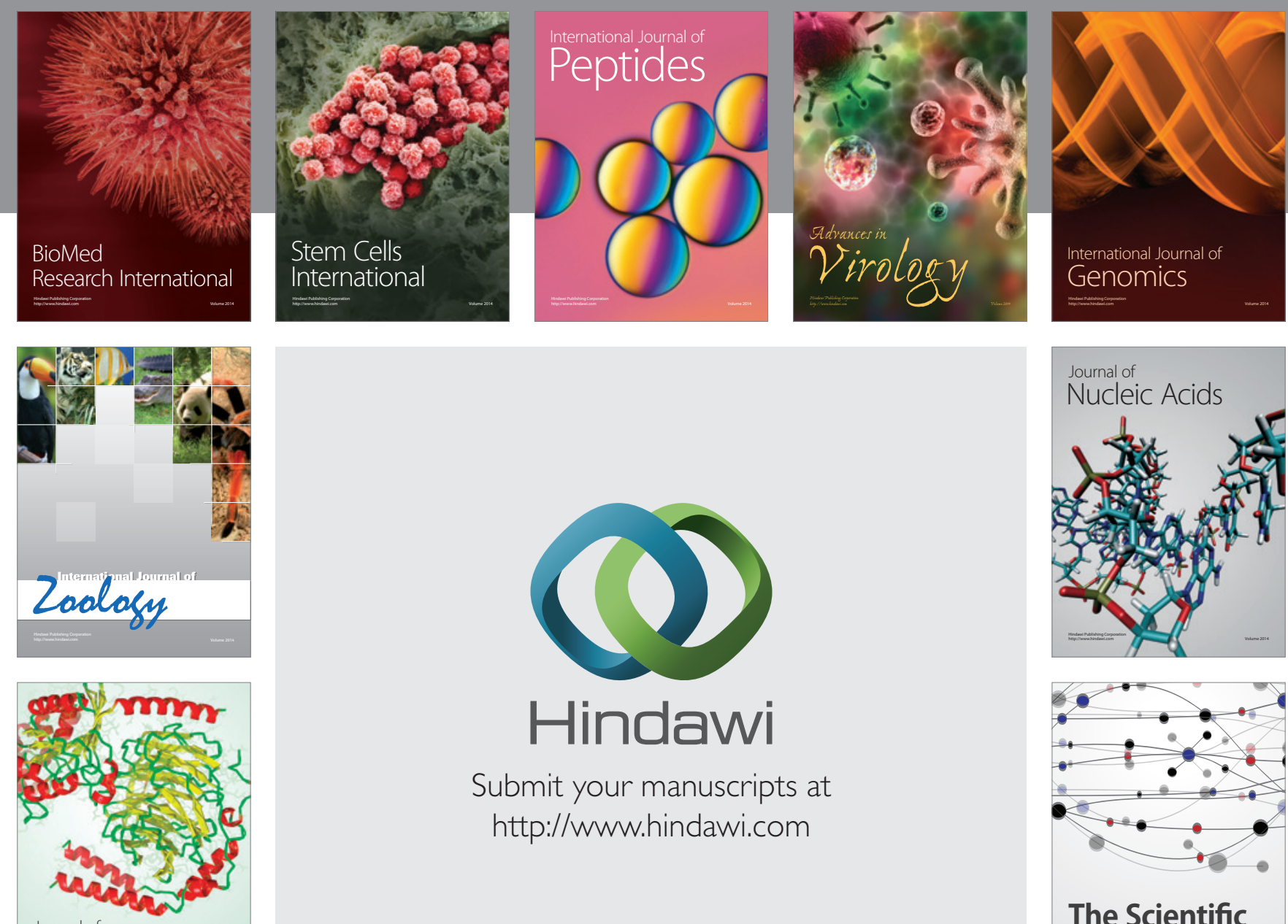

Submit your manuscripts at

http://www.hindawi.com

Journal of
Signal Transduction
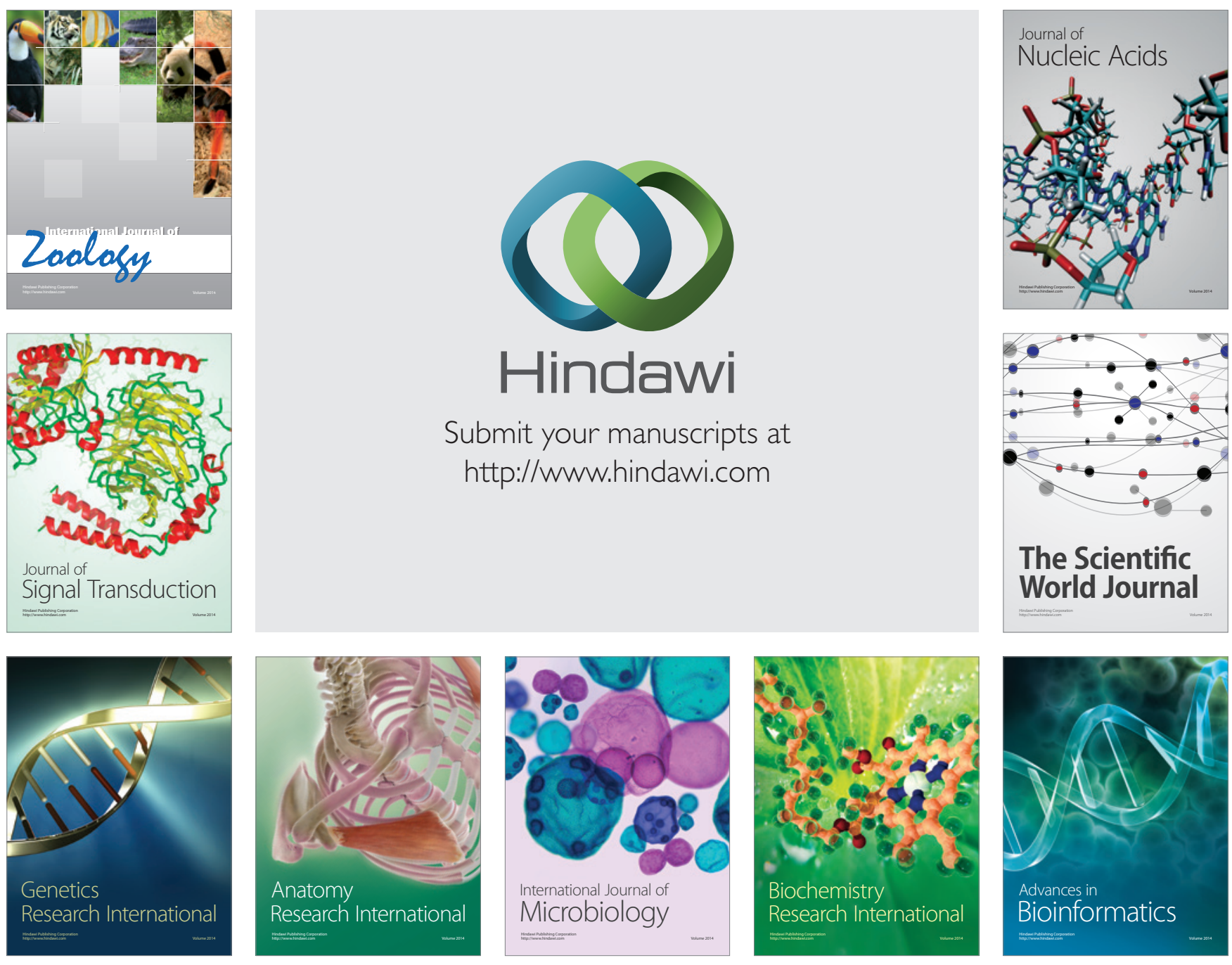

The Scientific World Journal
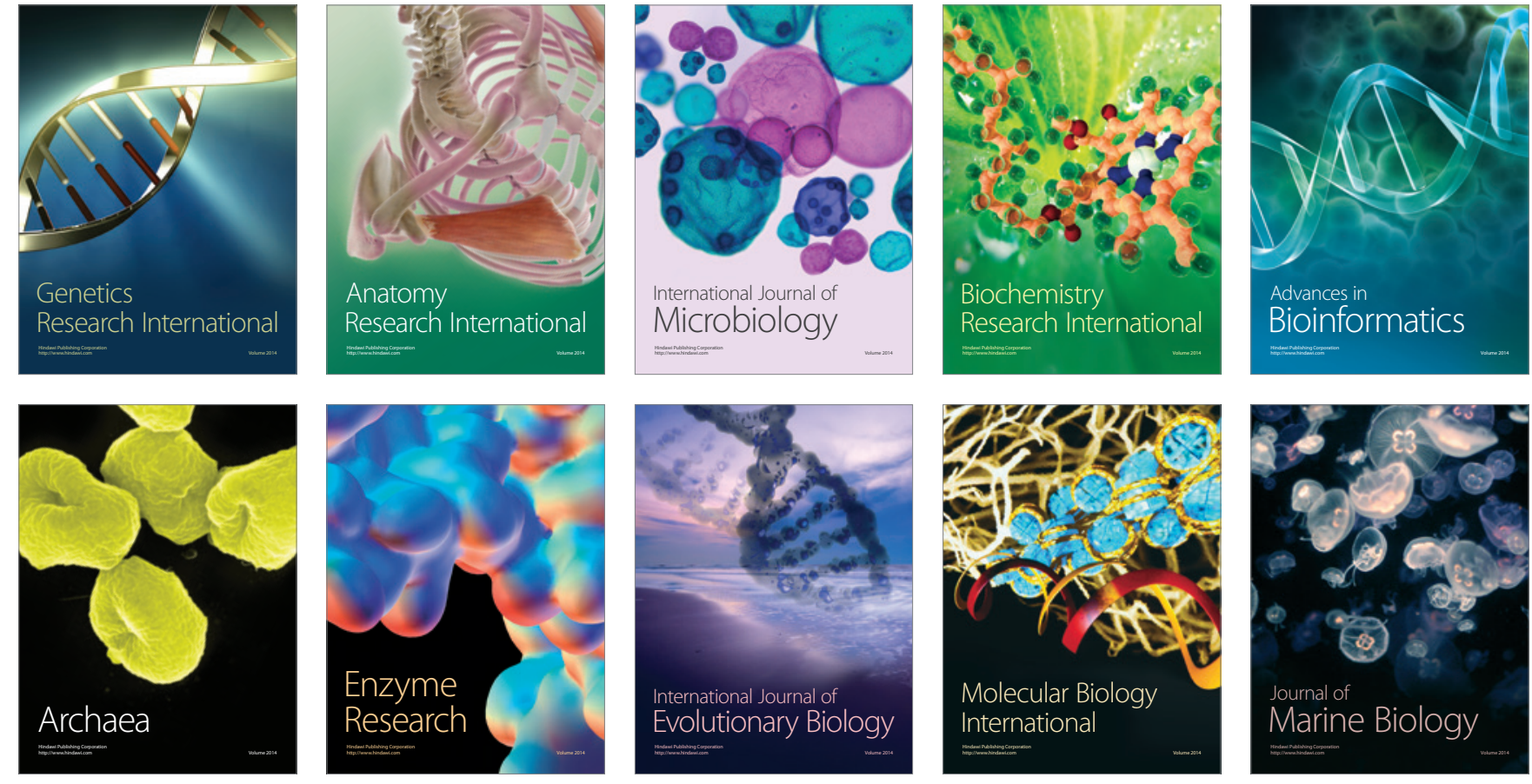